The Polish Journal of the Arts and Culture. New Series 11

(1/2020): 65-92 [ARTYKU‡]

DOI: $10.4467 / 24506249$ PJ.20.003.12989

\title{
Mimesis a duende. Proces kreacji flamenco w świetle koncepcji naśladownictwa w starożytnej estetyce greckiej
}

\author{
Krzysztof HLiniaK
}

\begin{abstract}
Streszczenie
Praca opisuje relacje naśladowania i twórczości we flamenco odnosząc je do greckiej koncepcji mimesis i porównując ją $\mathrm{z}$ obecną w tym gatunku koncepcją duende.

W celu ukazania fenomenu duende autor podejmuje się krótkiej odpowiedzi na pytanie, na czym polega fenomen flamenco, jakie są jego cechy charakterystyczne i z jakimi formami i stylami flamenco można się obecnie spotkać. Opisując fantazmaty dotyczące duende i pokazu flamenco autor przedstawia najważniejsze elementy jego kreacji.

Praca nawiązuje do dokonań filozofa Władysława Tatarkiewicza i jest hołdem złożonym zmarłej w 2018 roku profesor dr hab. Jagnie Dankowskiej.
\end{abstract}

Słowa kluczowe: flamenco, duende, mimesis, Federico García Lorca, naśladowanie

Krzysztof Huiniak doktorant III roku w Katedrze Porównawczych Studiów Cywilizacji Uniwersytetu Jagiellońskiego; absolwent historii i Podyplomowych Studiów z Zarządzania Kulturą tej uczelni, Podyplomowych Studiów Teorii Tańca na Uniwersytecie Muzycznym imienia Fryderyka Chopina oraz Instruktorskiego Kursu Kwalifikacyjnego z tańca współczesnego MKiDN; nauczyciel; od roku akademickiego 2018/2019 w ramach grantów z programu Biate plamy - muzyka i taniec Instytutu Muzyki i Tańca w Warszawie kieruje pracami badawczymi nad historią tańca w Krakowie i regionie; ma na koncie publikacje w czasopiśmie Studia Choreologica, kwartalniku Taniec i na portalu taniecpolska.pl; członek Stowarzyszenia Polskie Forum Choreologiczne i Stowarzyszenia Forum Środowisk Sztuki Tańca; w zakresie zainteresowań zajmuje się antropologią tańca i zagadnieniem dziedzictwa tanecznego.

E-MAIL: krzysztofhliniak@gmail.com 


\section{Profesor dr hab. Jagnie Dankowskiej}

Praca poświęcona profesor dr hab. Jagnie Dankowskiej (zmarłej 28 października 2018 roku), reżyser dźwięku, dr hab. filozofii, prof. Uniwersytetu $\mathrm{Mu}-$ zycznego Fryderyka Chopina w Warszawie, która swoją wiedzą, pasją muzyczną, umiłowaniem filozofii i serdecznym podejściem inspirowała swoich uczniów i mnie osobiście w trakcie Podyplomowych Studiów Teorii Tańca do dalszej aktywności na polu naukowym.

\section{Wstęp}

Flamenco kojarzy się powszechnie z barwnymi sukniami kruczowłosych tancerek $^{1}$, fiestą ${ }^{2}$, kastanietami i gorącym południowym temperamentem. To także ekspresyjny taniec, wirtuozowska gra na gitarze i trudny w odbiorze dla przeciętnego widza śpiew. W przypadku tego gatunku problem twórczości, odtwórczości i ich wzajemnych relacji jest zagadnieniem frapującym, które pobudza do refleksji. Zagadnieniem, które z racji mojej własnej praktyki scenicznej w tym zakresie wielokrotnie pojawiało się w rozmowach $\mathrm{z}$ innymi artystami.

Przedstawiając zjawisko flamenco i odnosząc się do kwestii twórczości i odtwórczości, w niniejszym artykule zostanie scharakteryzowana nieoczekiwana zbieżność założeń greckiej koncepcji mimesis i idei duende - demona, ducha flamenco. Omówiony zostanie związek obu koncepcji z procesem kreacji występu i choreografii flamenco oraz w tym kontekście opisany fenomen tego gatunku, jego cechy charakterystyczne oraz formy i style, z którymi można się spotkać ${ }^{3}$.

${ }^{1}$ Na określenie koloru włosów tancerek flamenco w języku hiszpańskim funkcjonują sformułowania pelo de color azabache, porównujące kolor włosów do gagatu - minerału, który $\mathrm{w}$ świetle nabiera granatowego lub fioletowego połysku i pelo de color cuervo od hiszpańskiej nazwy kruka, którego pióra także mają granatowy odcień. Stąd w Polsce spotkać można określenie „kruczoczarny”, a tancerki są kruczowłose. Azabache [w:] Diccionario de la lengua española, Real Academia Española;

2 Fiesta - dzień wolny, świąteczny, uroczystość kościelna lub świecka, zabawa z okazji dnia wolnego lub święta, fiesta, Diccionario de la lengua española, Real Academia Española.

3 Kwestia kreacji flamenco szerzej przedstawiona została w pracy K. Hliniak, Flamenco - zdarzenie magiczne, czy wiedza? Fantazmaty o nauczaniu i kreacji tańca. 


\section{Flamenco i jego twórcy}

Flamenco uznawane jest za zjawisko dotyczące śpiewu, muzyki, tańca i obyczajowości, które obejmuje Andaluzyjczyków i innych twórców hiszpańskiego pochodzenia, Gitanos - Romów zamieszkujących Andaluzję, inne regiony Hiszpanii i będących na emigracji oraz aficionados - miłośników i wykonawców tej stylistyki na całym świecie 4 . Od 2010 roku flamenco jest wpisane na listę niematerialnego dziedzictwa kulturowego UNESCO${ }^{5}$.

W historii flamenco splecione są dzieje Hiszpanii i Andaluzji, własna historia Romów i przemiany kulturowe, którym podlegała kultura europejska w XIX i XX wieku.

Do końca XX wieku flamencologia akcentowała romskie pochodzenie tego gatunku traktując go przede wszystkim jako część tradycyjnej kultury tamtejszych Gitanos. Zgodnie z tą wizją historii flamenco przez wieki pobytu Gitanos w Hiszpanii, ich indyjskie dziedzictwo miało stapiać się w andaluzyjskim tyglu z innymi tradycjami kulturowymi tworząc nową jakość. Żydowskie, arabskie, mauretańskie, północnoafrykańskie i hiszpańskie wpływy, latynoamerykańskie oddziaływanie po odkryciu Nowego Świata i romska tradycja miały stworzyć pod koniec XVIII wieku gatunek, który od połowy XIX wieku nazywano flamenco. Koncepcja akcentująca wpływ Gitanos na rozwój tego gatunku jest dalej obecna w dyskursie o flamenco i przedstawiana przez instytucje zajmujące się badaniami na jego temat (Cruces Roldán 2020). Próby tworzenia flamenco i mówienia o nim w oderwaniu od dziedzictwa Romów budzą kontrowersje i sprzeciw części społeczności cygańskiej ${ }^{6}$.

4 Ponieważ zjawisko flamenco łączy w sobie wiele dziedzin, na jego określenie w tekście użyto synonimicznie pojęć: kultura, styl, gatunek, stylistyka, sztuka.

5 Representative List of the Intangible Cultural Heritage of Humanity.

6 ArtykułyAcerca del enorme racismo de la cantante Rosalía hacia el pueblo romaní; Acusan a Rosalía de «desgitanizar» la canción de los Chunguitos que cantóen los Goya. Oprócz koncepcji hybrydyzacji transkulturowej, która została omówiona w dalszej części artykułu i rzuca nowe światło na rozwój flamenco, w kontekście flamenco funkcjonuje obecnie również pojęcie desgitanización. Ma to być świadome praktykowanie flamenco w oderwaniu od romskiej tradycji i kontekstu oraz traktowania go jako części muzyki latino lub pop. Szczególnie intensywna dyskusja na ten temat dotyczy działalności hiszpańskiej wokalistki urodzonej w Katalonii - Rosalíi (Rosalía VilaTobella), której interpretacje utworów flamenco odbiegają od oczekiwań purystycznej części publiczności i wykonawców flamenco. Przykładem takiego występu jest wykonanie utworu zespołu Los Chunguitos podczas rozdania nagród Goya 2019. Wokalistka z powodu stosunku do dziedzictwa flamenco i swojej działalności przez niektóre środowiska posądzana jest o rasizm. 
Badania prowadzone w ostatnich latach pozwoliły jednak spojrzeć na flamenco jako zjawisko, którego rozwój i kształtowanie się jako osobnego stylu było efektem oddziaływania hiszpańskiego mitu o Andaluzji, romantycznej fascynacji ludowością i cygańskością widocznej w kulturze europejskiej oraz przemian społeczeństwa hiszpańskiego w XIX wieku. Flamenco byłoby więc efektem hybrydyzacji transkulturowej, która łącząc różne wpływy i tradycje stworzyła nową, inną jakość. To kultura świadomie kreowana przez członków hiszpańskiej bohemy, do której należeli przedstawiciele miejskiego proletariatu, inteligencji, artystów i Gitanos. Sztuka ta byłaby więc kulturą ośrodków miejskich, stylistyką wykreowaną, tradycją wynalezioną i zaimplementowaną ponownie w tym środowisku. Przedstawiona wyżej koncepcja, jak też aspekty przemian kulturalnych w Hiszpanii w II połowie XIX wieku, zostały omówione szeroko w pracach Gerharda Steingressa.

Hybrydyzacja transkulturowa według Steingressa jest też immanentną cechą flamenco, która stale towarzyszy jego rozwojowi, od momentu oddzielenia się go od folkloru andaluzyjskiego i pozwala mu pozostawać gatunkiem żywym, ulegającym przemianom w czasie (Steingress 2005, 128, 132, 133). Na polskim gruncie koncepcję Steingressa, jak też dzieje flamenco przedstawiła Emilia Dowgiało (Dowgiało 2018), kwestię współczesnego, skomplikowanego dyskursu na temat flamenco omówiła natomiast Marta Wieczorek (Wieczorek 2018b - Flamenco: Contemporary Research Dilemmas).

Pamiętając o romantycznym wpływie na flamenco i roli andaluzyjskiej bohemy w jego powstaniu, które akcentują nowe badania, nie można zapominać o tym, że dzieje Romów i historia nazwy gatunku nie są jeszcze w pełni wyjaśnione $^{7}$. W oczach przedstawicieli hiszpańskiej i europejskiej kultury, społeczność obwarowana niezrozumiałymi przez nich zasadami, w tym obowiązkiem przestrzegania zasad Mageripen czystości-nieczystości rytualnej, określonych w niepisanym kodeksie postępowania, nazywanym przez środkowoeuropejskich Romów Romanipen, a po hiszpańsku La ley gitana (Ficowski 2000, 54; Fraser 2001, 180-181) ${ }^{8}$, była bardzo dobrym obiektem domysłów i kreowania mitów na jej temat. Sama jednak również te mity tworzyła

7 Zagadnienie nazwy gatunku i jej pochodzenia zostało opisane w artykule: K. Hliniak, Flamenco zdarzenie magiczne, czy wiedza? Fantazmaty na temat pochodzenia Gitanos, nazwy ich sztuki i jej twórcach.

8 Pojęcia Mageripen i Romanipen są pisane zarówno wielkimi, jak i małym literami, niezależnie czy publikacja została napisana przez członka społeczności romskiej czy też gadźo (hiszp. payo) - obcego (Adamczyk 2011, Bartosz 2003, Romano Atmo nr 5/2011 (11), Ramanipen, http://romopedia.pl/). 
i podtrzymywała9. Gitanos wywarli bezsprzecznie znaczący wpływ na tę sztukę, ale równie istotną rolę w jej przemianach odgrywali twórcy niemający romskiego pochodzenia, a ich działalność wydaje się być często kluczowa i przełomowa w rozwoju tego gatunku (Wieczorek 2018a, 29-32; Hliniak 2018, 230-239).

\section{Formy i style flamenco}

Przy rozważaniu kwestii kreacji, twórczości i odtwórczości we flamenco istotna jest próba odpowiedzi na pytanie, z jakimi formami gatunku mamy do czynienia i czy możliwe jest postawienie granic między nimi?

Flamenco ma formę uznawaną za tradycyjną, przekazywaną z pokolenia na pokolenie i uprawianą przez mieszkańców Hiszpanii i Andaluzji, w tym przez tamtejszych Gitanos. W tym kształcie kultywowane jest w kontekście rodzinnym i lokalnym. Miejscem publicznej prezentacji tego wyrazu sztuki flamenco są najczęściej peñas flamencas - lokale, a raczej wspólnoty aficionados - miłośników pielęgnujących jego tradycyjną formę. Pokazy, choć wstęp na większość z nich jest płatny, mają prawie prywatny charakter (Wieczorek 2018a, 52-55).

Choć zgodnie ze stanem dzisiejszych badań określanie sztuki Gitanos przed połową XIX wieku mianem flamenco, jak też wiązanie jego powstania tylko z tą grupą etniczną, jest nieuzasadnione, warto zauważyć, że istnieją świadectwa o pokazach tańców cygańskich z XVII wieku, mówiące o ich

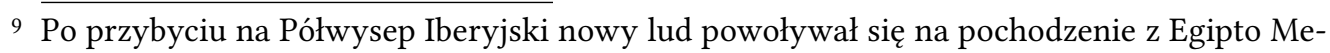
nor, Pequeño Egipto - Małego Egiptu. Określenie to jest przeinaczeniem nazwy miasta Meto-

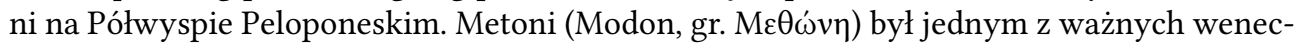
kich portów na terenie Grecji i punktem tranzytowym na drodze pielgrzymów z Europy do Ziemi Świętej, w którym odnotowano obecność Cyganów w tym okresie. Odwoływanie się przez Romów do „egipskiego” pochodzenia potwierdza przywilej wydany przez Alfonsa V w 1425 roku dla Juana de Egipto Menor. W nawiązaniu do tego źródłosłowu w Hiszpanii no-

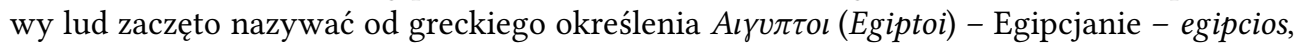
egipcianos lub egiptanos, co dało początek hiszpańskiemu Gitanos i angielskiemu Gypsies. Używano też określeń griecianos, grecos, romani, calés. Większość nazw, jakimi określano tę społeczność i stosowanych do dzisiaj jak hiszpańskie Zingaros, niemieckie Zigeuner czy

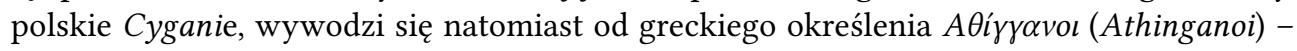
niedotykalni, którym prawdopodobnie nazywano ją od czasu pobytu w Cesarstwie Bizantyńskim (Leblon 1995, 151-153; Molina 1996, 28; Wielka Historia Świata. T. 17. Średniowiecze. Cesarstwo Niemieckie - Arabowie na pótwyspie pirenejskim, 232-233; Nueva teoría sobre el origen de los gitanos los vincula con el dios Krishna; Ficowski 2000, 6). 
specjalnym przygotowaniu na występy na dworach hiszpańskich arystokratów i władców. W XVIII wieku wzmiankowane są komercyjne pokazy tańców wykonywane przez Gitanos w podejrzanych lokalach w miastach Andaluzji (Dowgiało 2018, 42-43).

Od końca lat 40. XIX wieku pierwsze formy preflamenco pokazywane były na scenach cafes cantantes - kawiarni artystycznych, z których najsłynniejsze było Cafe de Silverio założone przez Silverio Franconettiego w 1881 $\mathrm{roku}^{10}$. Komercyjne potraktowanie flamenco przez Franconettiego było prawdopodobnie jednym z faktów konstytuujących tę sztukę jako osobny gatunek, oddzieliło ją od folkloru i podniosło znaczenie śpiewu flamenco. Od początku gatunek ten miał więc formę komercyjną i opracowaną artystycznie. Okazało się to szkodliwe dla poziomu tej sztuki pod koniec XIX wieku, gdy zaczęła schlebiać niskim gustom (Dowgiało 2018, 115-116).

Obecnie komercyjna forma tej sztuki przedstawiana jest głównie turystom w tablaos - scenach flamenco. Można w nich spotkać zarówno spektakle na bardzo wysokim poziomie artystycznym, jak i takie, które nastawione są tylko na zaspakajanie stereotypowych wyobrażeń o muzyce i tańcu flamenco. Od końca XIX wieku flamenco prezentowane było także na scenach teatralnych i operowych (Leblon 1995, 158-159; Ríos Ruiz 1997, 25-30; Tablao).

Do flamenco można zaliczyć również większe taneczne formy sceniczne bliższe baletowi, oparte na rytmice i stylach typowych dla tej sztuki, posiadające fabułę i odwołujące się do twórczości hiszpańskich poetów lub opowieści ludowych. Ich tematyka związana jest z losem Gitanos, tradycyjnym życiem w Andaluzji i mitami na jego temat. Jednymi z pierwszych spektakli tego typu były wystawienia baletu Manuela de Falli El amor brujo w 1915 roku w układzie tańca Pastory Imperio i w 1925 roku z choreografią Antonii

${ }^{10}$ Określenie flamencos pojawiło się początkowo w I połowie XIX wieku jako nazwa ludzi wykonujących charakterystyczny śpiew, muzykę i taniec, dopiero po pewnym czasie stało się określeniem gatunku taneczno-muzycznego. Do dzisiaj funkcjonuje jako określenie ludzi zajmujących się tą dziedziną. Także w Polsce potocznie w języku środowiska flamenco używa się określenia „flamenkosi”. Nie wszyscy mieszkańcy Andaluzji utożsamiają się z tą kulturą, jak też są Gitanos, którzy się od niej odcinają. W Hiszpanii mieszkają też Zingaros Romowie, którzy przywędrowali doń w późniejszych wiekach i nie są związani z kulturą flamenco. Równocześnie już od II połowy XIX wieku flamenco zajmują się osoby zamieszkujące w Andaluzji a nie będące Gitanos. Notowane są przypadki, że pod koniec XIX wieku artyści flamenco nie mający cygańskich korzeni fałszowali swoje pochodzenie, by móc prezentować ten gatunek. W Andaluzji żywy jest również folklor ludowy a niektóre style muzyczno-taneczne są obecne zarówno w nim, jak i we flamenco (Hliniak 2019). 
Mercé La Argentiny. Sukces tej drugiej realizacji zaowocował powstaniem w 1928 roku Les Ballets Espagnols, pierwszego baletu flamenco (Dowgiało 2018, 120-121).

Podobna forma przedstawień rozwinęła się szczególnie w II połowie XX wieku a jej najsłynniejszymi twórcami byli Antonio Gades i Cristina Hoyos a obecnie - Sara Baras. Spektakle w podobnym charakterze prezentowane są także przez Ballet Flamenco de Andalucía istniejący przy Junta de Andalucía i Ballet Nacional de España (Wieczorek 2018a, 108-111, Ballet Nacional de España, Ballet Flamenco de Andalucía) ${ }^{11}$. Działalność tych zespołów łączy klasyczny taniec hiszpański, flamenco i hiszpański folklor z baletem i tańcem współczesnym. Powstaje w ten sposób nowa, inna jakość, w której jednak style flamenco są rozpoznawalne. Część z tych spektakli jest wierna tradycyjnym formom, w części z nich są one na tyle przetworzone, że sztuka ta nie należy już do kultury tradycyjnej.

Między formami flamenco uprawianymi w rodzinach i lokalnie a scenami teatrów widać zbieżność i kontinuum. Można powiedzieć, że tego typu relacja między kulturą tradycyjną, folklorem a scenami teatrów i salami szkół tańca jest cechą właściwą dla kultury hiszpańskiej od XVIII wieku. $\mathrm{W}$ tym czasie popularne formy zaczerpnięte $\mathrm{z}$ folkloru znajdowały miejsce w repertuarze ówczesnych teatrów a jednocześnie jako opracowane artystycznie $\mathrm{z}$ biegiem czasu ponownie były przyswajane przez lud (Dowgiało 2018, 38-41).

We współczesnym flamenco zbieżność form tradycyjnych i opracowanych artystycznie dotyczy przedstawianych stylów, techniki tanecznej, wokalnej i gitarowej, a także tematyki przedstawień. Tancerze, śpiewacy i muzycy coraz częściej kształceni w konserwatoriach muzycznych i szkołach baletowych znają tradycyjne formy flamenco, nierzadko pochodzą z rodzin kultywujących tę kulturę od pokoleń. Włączają te formy w swoje spektakle i sami je prezentują. Często program przedstawień granych w teatrach i opartych na twórczości hiszpańskich dramaturgów i poetów zawiera w sobie bisy w formie improwizowanej części por fiesta, w której biegłością w wykonywaniu tradycyjnych stylów flamenco, głównie bulerías, popisują się artyści biorący udział w spektaklu. Taką formę ma między innymi spektakl Mariana Pineda będący taneczną adaptacją dramatu Federico Garcii Lorki,

${ }^{11}$ Ballet Nacional de España; Ballet Flamenco de Andalucía. Ballet Nacional de España prowadzony jest obecnie przez tancerza flamenco Rubéna Olmo, który do 2019 roku był choreografem Ballet Flamenco de Andalucía. 
który zrealizowała Sara Baras ${ }^{12}$. Wpływy te mają charakter dwukierunkowy. W klubach, w których odbywają się pokazy flamenco, także te dla turystów, można odnaleźć nawiązania do twórczości muzyków, śpiewaków i tancerzy znanych ze scen teatralnych a preferowane palos - style to te, które widać na wielkich scenach.

Przedstawiony podział form flamenco przypomina nieco rozróżnienie polskich tańców ludowych na tradycyjne i przedstawiane jako autentyzowane, opracowane artystycznie i stylizowane. Trzeba jednak zastrzec, że w przypadku flamenco łączność między tymi kategoriami jest zdecydowanie bardziej zachowana i żywa, a granica między nimi płynna (Burszta 1985, $311-328)$.

Trudno więc czasami precyzyjnie rozgraniczyć, kiedy powyższe formy pokazów flamenco możemy nazwać tradycyjnymi, a kiedy nie. Od połowy XVIII wieku istnieje bowiem także escuela bolera - styl tańca inspirowany hiszpańskim folklorem, z którego flamenco wiele czerpało i który prawdopodobnie wyparło z lokali i scen (Steingress 2005, 129; Dowgiało 2018, 38). Sprawę utrudnia obecność nawiązań i inspiracji flamenco w zarzuela - łączącej części mówione, śpiewane i tańczone hiszpańskiej operetce i w copla (copla andaluza, copla española, canción andaluza, canción española) - sztuce wokalnej, która powstała w Hiszpanii w latach 20. XX wieku. Warto też zauważyć istnienie danza española - klasycznego tańca hiszpańskiego, który łączy dziedzictwo różnych regionów Hiszpanii i balet klasyczny, i w formie tańca charakterystycznego stał się częścią sztuki baletowej. Powyższe klasycyzujące formy kultury hiszpańskiej: zarzuela, copla i danza española były szczególnie preferowane przez władze w czasie dyktatury generała Francisco Franco w latach 1939-1975. Na ich bazie frankistowski reżim próbował stworzyć jednolity styl hiszpańskiej sztuki narodowej, w którym flamenco miało pełnić rolę egzotycznego, atrakcyjnego dodatku, oczyszczonego jednocześnie z odniesień do dziejów i faktycznej sytuacji dyskryminowanych Gitanos w ówczesnej Hiszpanii (Goldbach 2014, s. 20-21; Wieczorek 2018a, $151,153-155,163)^{13}$.

${ }^{12}$ Mariana Pineda. Por fiesta (hiszp. dosłownie dla zabawy) - z założenia improwizowany, spontanicznie podejmowany występ, zazwyczaj taneczny (bulerías, tangos), w którym biorą udział uczestnicy zabawy, spotkania lub koncertu flamenco.

${ }^{13}$ Fascism, flamenco, and ballet español. Nacional flamenquismo, s. 20-21; M. Wieczorek, Flamenco. Studium z antropologii semiotycznej, s. 151, 153-155, 163; zarzuela [w:] Diccionario de la lengua española, Real Academia Española; copla [w:] Diccionario de la lengua española, Real Academia Española. 
Zarówno w tych tradycyjnych, jak też w autentyzowanych, opracowanych artystycznie i stylizowanych formach przedstawien flamenco wykorzystywane są tradycyjne palos - style, które kształtowały się od II połowy XVIII wieku.

Współczesne style flamenco według najbardziej powszechnej klasyfikacji dzieli się na dwie grupy. Pierwsza to: cante chico (śpiew wesoły) - style o radosnym charakterze, m.in.: alegrias, bulerias, tanguillo wyróżniając wśród nich cantes de ida y vuelta (pieśni drogi i powrotu), style które przywędrowały do Hiszpanii z Nowego Świata, jak: guajira, colombiana, rumba gitana.

Druga grupa to cante jondo, nazywane też cante grande (śpiew głęboki, wielki) - style o poważnym charakterze, m.in.: soleares, siguiriyas, saeta. Style pośrednie między cante chico a cante jondo, np. fandangos de Huelva zalicza się czasami do cante intermedio. Niektóre ze stylów w zależności od maniery wykonawczej i charakterystyki ruchowej mogą być zaliczane tak do flamenco, jak i do folkloru. Takimi są sevillanas i fandangos.

Wykonywany repertuar w ciągu prawie dwóch wieków ulegał i ulega wciąż przemianom. Są style, których wykonania można rzadko oglądać, np. farruca, guajira i garrotin, i takie, bez których nie może obyć się koncert flamenco, jak soleares, seguiriyas i alegrias. Żaden występ, ale również spotkanie aficionados nie może odbyć się bez takich palos jak bulerias, tangos i rumba gitana. Niektóre ze stylów wykonywane są tylko okolicznościowo, jak saeta $\mathrm{w}$ trakcie Wielkiego Tygodnia, czy villancicos - kolędy w okresie Bożego Narodzenia. Wiele stylów, w tym tangos, fandangos i bulerias ma odmiany lokalne, które różnią się od siebie strukturą i charakterystyką muzycznoruchową (Zgraja 1995, 12-13).

Trudno jednak mówić o kanonie stylów flamenco podobnym do kanonu polskich tańców narodowych. Można wyróżnić kilkadziesiąt gatunków wykonywanych przez gitarzystę solo, gitarzystę i śpiewaka, samego śpiewaka, tancerza solo, gitarzystę i tancerza lub przez cuadro flamenco - zespół złożony ze śpiewaka, gitarzysty, tańczących oraz innych muzyków.

\section{Mimesis a duende}

Flamenco jako samodzielna forma powoli krystalizowało się około połowy XIX wieku, a w II połowie wieku wyodrębniło się z folkloru andaluzyjskiego (Dowgiało 2018, 80, 85). W tym czasie powstawał wzorzec czym jest, a czym nie jest ta dziedzina sztuki. Odtąd konfrontowali się i konfrontują 
z tym wzorcem ci, którzy zajmują się tym gatunkiem. Relacja między idealnym wyobrażeniem flamenco a jego twórcami zostanie przeanalizowana w odniesieniu do greckiego pojęcia mimesis, którego charakterystykę przedstawił Władysław Tatarkiewicz w publikacji Dzieje sześciu pojęć (Ríos Ruiz 1997, 25-30, Tatarkiewicz 2006, 319 i n.).

By lepiej opisać proces kreacji występu i choreografii flamenco warto jeszcze omówić funkcje jakie spełnia ten gatunek. Roderyk Lange wymienia wielorakie funkcje, które spełnia taniec, a które można również odnieść do sztuki flamenco. Są to:

- funkcja społeczna - tworząca zręby tożsamości i ustalająca normy w danej społeczności,

- magiczno-religijna - mająca zapewnić powodzenie i dostatek jednostkom i grupie,

- ludyczna - czasami mająca charakter tożsamy z funkcjami teatralną i edukacyjną.

Istotną cechą tańca tradycyjnego, nawet gdy mamy do czynienia $\mathrm{z}$ tradycją wynalezioną, jest przekonanie o jego niezmienności i wyjątkowości. Flamenco spełnia wymienione funkcje tańca, a wśród uprawiających ten gatunek jest bardzo silne przekonanie o jego szczególnym, wyjątkowym miejscu pośród innych rodzajów kultury i sztuki (Lange 2009, 102-103, 110).

Władysław Tatarkiewicz pisał, że sztuka może obejmować dzieło doskonałe w formie, może także oznaczać twórczość, której zadaniem jest kreowanie czegoś nowego, ale także taką, która ma wzruszać i wzbudzać zachwyt (Tatarkiewicz 2006, 294-295). Większość występów flamenco spełnia jedno, oba lub wszystkie te kryteria. Oczywiście stopień ich realizacji może być różny, ale zgodnie z najszerszym i współczesnym rozumieniem pojęcia sztuki można bezsprzecznie uznać, że flamenco nią jest.

Czy każdy pokaz flamenco będzie sztuką? Zapewne niektórym z pokazów bliżej będzie do greckiego techne - biegłości technicznej niż do poiesis przeżycia duchowego (Tatarkiewicz 2006, 320; Grzybowski 2006, 5-6). Każdy zajmujący się flamenco zna, przeczuwa, bądź wyobraża sobie jego wzorzec i intuicyjnie określa czy to, co widzi jest wyrazem znajomości techniki, czy dostarcza mu również przeżyć duchowych. Powstaje więc pytanie, na ile wykonawca flamenco jest twórcą, a na ile odtwórcą dzieła. W ten sposób stawiane w starożytności pytanie, czym jest mimesis, również będzie dotyczyć twórczości flamenco. 
Odpowiedź na pytanie, czym jest naśladowanie, twórczość i odtwórczość dla samych Greków nie była jednak łatwa. Ze starożytną Grecją kojarzymy bowiem aż cztery sposoby rozumienia mimesis.

Pierwsze mimesis posthomeryckie, misteryjne, świadomie zostanie teraz pominięte, gdyż, choć najstarsze chronologicznie, jak zostanie dalej wykazane, jest najbliższe XX-wiecznemu myśleniu flamenco o sobie samym.

Druga jest myśl Demokryta, który mimesis rozumiał jako naśladowanie sposobów działania natury. Flamenco nie pochodzi z natury, można powiedzieć, że przeciwnie - jako sztuka objawiło się w środowisku miejskim. Wydaje się, że trudno koncepcję Demokryta odnosić do tej dziedziny. W starożytnej kulturze greckiej takie rozumienie mimesis także nie znalazło wielu zwolenników.

Trudno do flamenco odnosić ścisłe rozumienie platońskiego powtarzania wyglądu rzeczy. Jednak jeżeli rozumieć platońskie mimesis jako naśladowanie wzorca, który powstał w przeszłości, albo istnieje w idealnym świecie, to możemy je odnieść do flamenco. W sferze wyobrażeniowej istnieje wzorzec flamenco, a jak pokazuje wspomniany wcześniej dyskurs o dziejach i formach flamenco - nawet kilka wzorców, do których wykonawcy odnoszą się tworząc swoje dzieła (Tatarkiewicz 2006, 320, Grzybowski 2006, 36-37).

Idealny wizerunek flamenco, który kształtował się w II połowie XIX wie$\mathrm{ku}$ pod wpływem przemian opisanych wyżej, połączył w sobie lokalne tradycje muzyczne, hiszpańską idylliczną wizję Andaluzji, romantyczne zainteresowanie ludowością, Cyganami, orientem i ogólnie pojmowaną egzotyką.

Istotna dla fantazmatu flamenco jest także obecność hiszpańskich motywów w operach i baletach komponowanych w XIX i XX wieku przez twórców z Hiszpanii i zagranicy, opartych na tematyce związanej z krajem na południe od Pirenejów. Do najważniejszych należy zaliczyć pokazany w 1836 roku balet Le diable boiteux $\mathrm{z}$ tańcem la cachucha w oryginalnym wykonaniu Fanny Elsler, która swoim występem rozpoczęła ogólnoeuropejską karierę tańca hiszpańskiego i słynną Carmen Georgesa Bizeta opartą na noweli Prospera Meriméego i wystawioną w 1875 roku (Turska 1983, 154; Turska 2014, 63-68; Dowgiało 2018, 55-57). Do flamenco nawiązywał i w swojej twórczości świadomie kreował jego cygańską wizję wspomniany już kompozytor Manuel de Falla (Ríos Ruiz 1997, 133-134; Turska 2014, 86-89, 436-439).

Do ugruntowania fantazmatu flamenco w zdecydowany sposób przyczynił się Primer Concurso Nacional de Cante fondo de Granada w 1922 roku. Organizujący go, w tym Federico García Lorca i Manuel de Falla, odwoływali 
się do mitycznych początków flamenco rozumianego jako wyraz sztuki prymitywnej i do jego cygańskiej tradycji. Wzmocnili istniejące i wykreowali następne przekonania o tej sztuce. Jednym $\mathrm{z}$ nich było stworzenie fantazmatu flamenco puro, wzorca do którego powinny nawiązywać kolejne pokolenia wykonawców. Bardzo istotny dla sztuki flamenco jest też wykreowany przez Lorkę ideał duende, który został opisany w dalszej części tego tekstu. Konkurs w Granadzie dał flamenco podwaliny teoretyczne i tym samym przyniósł nobilitację tego gatunku wśród hiszpańskiej inteligencji (Leblon 1995, 169, Turska 2014, 86-87, 436, 438; Turska 1983, 272-273; Dowgiało 2018, 122-125).

Do utworów Lorki dalej nawiązują współcześni artyści, flamencolodzy i kultura popularna. Z wykreowanym w XIX i na początku XX wieku wizerunkiem mieszkańców Andaluzji można spotkać się w utworach dramatycznych Lorki Mariana Pineda, Krwawe gody czy Yerma, które wciąż są wystawiane na deskach hiszpańskich teatrów i scenach baletowych ${ }^{14}$.

Wzorzec i wyobrażenie flamenco jako sztuki tradycyjnej podtrzymał Concurso Nacional de Arte Flamenco de Córdoba w 1956 roku, działalność Antonio Maireny i kolejne inicjatywy, w związku z którymi lata 1950-1980 nazywa się w tradycyjnej flamencologii Renacimiento - odrodzeniem flamenco. W myśl istniejącego fantazmatu flamenco puro pod tym określeniem rozumiano odwoływanie się twórców do tradycyjnej, zamkniętej na zmiany wizji czystego gatunku.

Jego istotnym komponentem w przekazie emocjonalnym są: doświadczenie bycia odrzuconym, poczucie dyskryminacji, cierpienie i ból, ale też wzór mężczyzny jako silnego macho i tancerki będącej uosobieniem kobiecej zmysłowości. Istotne jest, że przy krytycznym podejściu do postawy jaką reprezentowali ówcześni zwolennicy stylistycznej czystości flamenco, ich działalność przyczyniła się jednak do profesjonalizacji tej sztuki i wzrostu jej prestiżu (Goldbach 2014, 69-71; Steingress 2005, 129-130, 136-137).

$\mathrm{Z}$ opisanym powyżej wzorcem flamenco mierzy się wielu współczesnych wykonawców i pedagogów tego stylu. Dla części wykonawców celem działania będzie jak najwierniejsze i najbardziej zgodne z powyższym wzorcem odtworzenie stylów i technik tańca, gry czy śpiewu, tak jak uprawiali je wielcy artyści lub też, jeżeli wykonują i nauczają flamenco poza Hiszpanią, tak jak robią to Andaluzyjczycy czy Hiszpanie. Celem tego działania jest perfekcja

${ }^{14}$ Teatralną twórczość Federico Garcii Lorki i jej związek z andaluzyjskim dziedzictwem omówiła Urszula Aszyk w publikacji Federico García Lorca w teatrze swoich czasów, s. 35-52. 
wykonawcza w naśladowaniu tego, co zostało stworzone i przekazane im przez innych i zgodność z przyjętymi zasadami gatunku, w tym dążenie do kreowania na scenie flamenco puro. Wielu z tych artystów uważa jakiekolwiek wykroczenie innych twórców flamenco poza obowiązujący wzorzec za powód do zanegowania wartości tak powstałego dzieła i uznania niekompetencji osób go tworzących.

Oczywiście w dążeniu do ścisłego naśladowania wzorca flamenco zdarzają się dzieła, które realizują w pełni postulat bycia dziełem doskonałym $\mathrm{w}$ formie, jak też potrafią zachwycać i wzruszać a dążenie do tak pojmowanej doskonałości nie zawsze należy oceniać negatywnie. Rygorystyczne podejście do twórczości flamenco jest też związane z silnie obecnym w tej kulturze fantazmatem o tym, że nikt nie będzie w stanie tak dobrze wykonać flamenco jak Gitanos, na co wskazuje poniższy cytat odnotowany w pracy Bernarda Leblona.

Obcy - może śpiewać lepszym lub gorszym głosem, głosem znakomitym, wyuczonym, ale Gitano śpiewa, bo żyje. Niesie na swoich plecach nagromadzone doświadczenia. Obcy śpiewa, ponieważ pamięta melodię. Śpiewa tak, jak ma być. Gitano śpiewając, cierpi, żyje i zbliża się do swoich przodków, dziadków i pradziadków. ${ }^{15}$

Dlatego właśnie kontrowersje wzbudzają twórcy, którzy przekraczają ustalone wzorce flamenco puro i łamią związane z nimi stereotypy kulturowe i społeczne. Wśród nich była tancerka Carmen Amaya, gitarzysta Paco de Lucía, szeroki nurt flamenco nuevo a teraz wokalistka Rosalía.

W kontekście flamenco warta zauważenia wydaje się teoria iluzjonizmu, czyli tworzenia rzeczy i rzeczywistości podobnych do prawdziwych (Tatarkiewicz 2006, 335; Tatarkiewicz 2011, 77-78). W tym gatunku szczególnie widoczne jest tworzenie iluzji świata jak najbliższego wyimaginowanej Andaluzji, która ma dać widzowi - a także często artyście - poczucie przeniesienia się do tamtej części Hiszpanii i uczestniczenia we wspólnocie z innymi zajmującymi się tą dziedziną sztuki. Fantazmat o Andaluzji towarzyszy

15 „El payo puede cantar con mejor o peor voz, con una voz brillante, unas facultades estupendas; el gitano expresa el cante porque lo vive. Son vivencias que tiene acumuladas a las espaldas. El payo lo está cantando porque está recordando la melodía. Lo canta como tiene que ser. El gitano lo está suffendo, viviendo y se está acordando, cuando está cantando, de sus padres, abuelos y tatarabuelos" (Leblon 1995, 170, tłum. K. Hliniak; Grzybowski 2006, 39). 
kulturze hiszpańskiej od wieków i od XIX wieku stał się częścią kultury europejskiej. Choć flamenco rozwijało się i zaistniało publicznie w miastach, wzorzec ten często odtwarza fantazmaty o wiejskim pochodzeniu flamenco i trudnym losie wędrujących Gitanos. Powstanie flamenco, przemiany tego gatunku, próba wykorzystania go dla celów ideologii frankistowskiej i międzynarodowa popularność artystów flamenco w II połowie XX wieku, nadały tym wyobrażeniom o flamenco wymiar globalny. Dziś taką wizję Andaluzji starają się kreować na scenach prawie wszyscy artyści flamenco, od Tokio po Warszawę.

Czasami tę iluzję udaje się osiągnąć przez pełną zgodność formalną i naśladowanie wzorca, czasami przez nawiązanie, zgodnie $\mathrm{z}$ arystotelesowskim rozumieniem mimesis, do ogólnych skojarzeń z południem Hiszpanii. W ten sposób nieodłączną częścią większości pokazów flamenco stały się kastaniety, wachlarze, chusty, falbaniaste spódnice i suknie w kolorze czerwonym, w białe bądź czarne grochy. Użycie powyższych akcesoriów ma uprawdopodobnić przedstawianą sytuację sceniczną i przybliżyć ją do tej idealnej (Żebrowska-Kacprzak 2011, 21-41, 51-67; Linares 1996, 156-157, Hliniak 2017, 108).

Swobodne i szeroko rozumiane pojęcie naśladowania, które cechuje Arystotelesa, bardziej pasuje do współczesnej twórczości flamenco niż poglądy Platona. Szczególnie gdy mowa o nurcie flamenco nuevo. Możliwość twórczego naśladowania, a więc własnego wkładu w dzieło sztuki, jak najbardziej odpowiada dzisiejszej wizji flamenco, a zgodnie z badaniami Gerharda Steingressa prawdopodobnie kształtowała tę sztukę u jej zarania. W XIX wieku wyrażała ona pragnienia, ideały i emocje bohemy andaluzyjskich miast odpowiadając jednocześnie na zapotrzebowanie publiczności na egzotykę i hiszpańskiego ducha.

W nurcie swobodnego traktowania naśladownictwa wzorów flamenco tworzy spora część artystów uważając wierność kanonom tej sztuki za niezaprzeczalną wartość, ale też wnosząc do niej to, co dla nich jest istotne. Można powiedzieć za Arystotelesem, że ich sztuka nie tylko jest sztuką naśladowczą, ale i wypełniającą dzieło nowymi treściami. Zmiany mogą dotyczyć charakteru ruchu, klimatu pokazu, akcesoriów czy stroju. Dzięki temu powstają dzieła formalnie zgodne $\mathrm{z}$ tą stylistyką, ale bardziej otwarte na dostosowanie jej do realiów otaczających artystę, a przez to czasami lepiej zrozumiałe dla miejscowego odbiorcy i nadążające za zmiennością gustów publiczności lub zmianami społecznymi. Przykładem takich zmian formalnych będzie 
działalność Carmen Amaya. Posiadała ona niesamowitą technikę tańca i ekspresję, które łamały obowiązujące w jej czasach stereotypy o kobiecym tańcu flamenco. Jako pierwsza $\mathrm{z}$ tancerek flamenco tańczyła w spodniach i styl zarezerwowany dla mężczyzn - farruca (Wysocka 1970, 249-250; Malska 1998, 13; Tatarkiewicz 2006, 322-323; Grzybowski 2006, 43, 48). W podobny sposób poza obowiązujące wzorce wychodzi dziś artysta Manuel Liñán. Jego spektakl en travestie pod tytułem ¡Viva! w wykonaniu męskiego zespołu, przekraczając kategorie płci, ukazuje z kolei kobiecą stronę flamenco. Jednocześnie dzieje się to przy pełnym poszanowaniu tradycyjnych wzorców związanych z tą sztuką, któremu towarzyszy perfekcja wykonawcza (Manuel Liñán).

Wykraczanie poza przyjęty kanon, w tym transkulturacja i tworzenie fuzji, a więc wnoszenie do realizowanych dzieł elementów innych kultur narodowych, czy tradycji kulturowych, może mieć wiele przejawów. Odbywa się na kilku płaszczyznach: formalnej, semantycznej i społeczno-kulturowej. Do przejawów tej fuzji można zaliczyć eklektyczny, formalny melanż gatunków, imitację czy pastisz. Fuzja, która odbywa się na głębszym poziomie i kreatywnie wykorzystuje różne tradycje może doprowadzić do wspominanej hybrydyzacji transkulturowej, tworząc nową, trzecią jakość. Fuzja i transkulturacja mogą mieć miejsce jednocześnie, odbywać się niezależnie, mieć miejsce w obrębie jednej, pozornie homogenicznej kultury lub też między różnymi tradycjami narodowymi (Steingress 2005, 132-133).

Koncepcja fuzji zbiega się z najczęściej spotykaną współcześnie teorią dotyczącą naśladowania i twórczości, teorią pluralistyczną i ze wspomnianą wcześniej koncepcją mimesis Arystotelesa (Tatarkiewicz 2006, 335-336). Wydaje się być szczególnie bliska flamenco i dzisiejszemu pojmowaniu roli artysty, który poprzez swoje dzieło wyraża idee i własne przeżycia, swobodnie korzystając z wolności twórczej.

Taka postawa pozwala artyście nie tylko na wyrażanie własnych emocji, ale też na twórcze przekształcanie tego stylu, jego rozwój i łączenie z innymi dziedzinami i gatunkami sztuki. Czasami odbywa się to w sposób zaskakujący czy kontrastowy. Dzięki temu sztuka pozostaje wciąż żywa, jednak takie podejście budzi znaczny sprzeciw wielu purystów flamenco.

W mniejszym stopniu niż powyższe teorie naśladowania, można wiązać z flamenco antyczny pogląd, że sztuka pozwala poznawać rzeczywistość. Występ flamenco był i jest kreacją pełną symboli i mitów. Stąd możemy oczywiście poznawać rzeczywistość pokazu, ale bardziej, choć w sposób zapośredniczony, zjawiska, które miały miejsce w kolebce flamenco i w toku jego 
rozwoju. W mniejszym stopniu występ pozwala na poznanie rzeczywistości jako takiej, aktualnej, odartej z przyjętych masek i fantazmatów, gdyż jak już wcześniej zostało powiedziane, flamenco najczęściej odtwarza powstały wcześniej wzorzec.

Trudno więc flamenco, mocno osadzone $\mathrm{w}$ fantazmatach powstałych w XIX i XX wieku, rozumieć jako znak czasów współczesnych, metaforę rzeczywistości czy odtworzenie obrazu dzisiejszego życia. Mająca bardzo silne założenia teoretyczne i ujęta w mocne schematy sztuka flamenco, powoli ulega przemianom i rzadkie są przypadki ukazywania przez nią współczesnego świata. Jest to sztuka realistyczna na tyle, na ile tworzą ją dzisiaj żyjący ludzie, ale raczej nie w tym, co przedstawia.

Wydaje się, że opisywana przez Steingressa fuzja flamenco i innych tradycji zachodzi w dziedzinie muzyki częściej i na głębszym poziomie, natomiast fuzja taneczna ma miejsce rzadziej, a wykonawcom trudniej przekraczać istniejące fantazmaty na temat tego gatunku. Wspominana wcześniej działalność Carmen Amaya, czy Manuela Liñána są w tym względzie raczej wyjątkami niż regułą. Flamenco w formie scenicznej ukazuje i odtwarza obraz wyobrażonej rzeczywistości z przeszłości, sprzed stu pięćdziesięciu, dwustu lat, z czasów swoich narodzin i Edad de Oro - Złotego Wieku, niż nawiązuje dialog z realnym światem. Odwoływanie się do tych fantazmatów podczas spektakli flamenco to właściwie paradygmat twórców tańca flamenco.

Inną perspektywę na flamenco, zarówno wierne tradycji, jak i wykraczające poza nią, daje porównanie jego założeń do pierwotnego pojmowania mimesis przez starożytnych Greków, rozumianego jako kultowe czynności kapłana, składające się z muzyki, tańca i śpiewu. Posthomerycka, misteryjna, pojetyczna mimesis miała wyrażać rzeczywistość wewnętrzną i była obrzędem zbliżonym do występu aktora. Było to postępowanie twórcze, ale nie wynikało z zamysłu kapłana, ale z przyjętej przez niego formy działania (Tatarkiewicz 2006, 320, 347).

Zbieżne z powyższym myśleniem wydaje się być pojęcie duende zastosowane do opisania flamenco przez Federico Garcíę Lorkę w początkach XX wieku.

Duende miałoby być demonem ogarniającym w czasie występu artystę i widzów, siłą wyższą, wobec której występujący musi się określić, z którą walczy i która nim kieruje. Siłą, po poddaniu się której, artysta może być naprawdę flamenco a jego przekaz pełny i autentyczny. W ten sposób przestawałoby się liczyć naśladowanie zewnętrznego wzorca a istotne byłoby to, 
co artysta wyraża w kontakcie z duende. Występ flamenco nie miałby być więc realizacją planowanego przedsięwzięcia scenicznego, ale doświadczeniem religijnym lub magicznym (Diez de Prado 2009, 4-5).

Powyższe doświadczenie duchowe nie będzie jednak tożsame z obecnością flamenco podczas procesji Semana Santa - Wielkiego Tygodnia, w czasie których wykonuje się styl saeta. Nie będzie też wprost powiązane z wykonywaniem w kościele, czasami jako części liturgii katolickiej mszy świętej, skomponowanych $\mathrm{w}$ tym celu mszy flamenco ${ }^{16}$. Nie wyklucza to działania duende $\mathrm{w}$ powyższych okolicznościach, jednak jak pisze Lorca, duende nie można łączyć z określoną religią (García Lorca 1933, 2).

Pozaziemski wpływ na artystę miałby być według Lorki zjawiskiem przypisanym nie tylko Hiszpanom. Jak pisze w swoim traktacie:

Wszystkie rodzaje sztuki, jak też kraje mają potencjał duende, anioła i muzy, i tak jak Niemcy mają, z wyjątkami, swoją muzę, i Włochom stale towarzyszy anioł, tak Hiszpania cały czas poruszana jest przez duende. ${ }^{17}$

Działanie duende miałoby jednak różnić się od wpływów anioła i muzy, oboje mają bowiem oddziaływać na artystę z zewnątrz. Anioł ma rozlewać nad twórcą swoją łaskę, ale artysta nie może mu się sprzeciwić i jest zmuszony do wypełniania przeznaczenia. Muza działa delikatniej przez ukazywanie artyście zwodniczych form, ale tym samym może prowadzić go do zatracenia. Duende ma natomiast wpływać na artystę od środka. Jest mocą a nie dziełem, walką a nie myśleniem, kreacją w działaniu i w związku z tym działanie duende za każdym razem będzie niepowtarzalne (García Lorca 1933, 2-3, 9; Martínez Hernández 2011, 93).

Artysta staje sam i odarty z tego, co posiada - wobec sztuki, miłości i śmierci. Dopiero ten stan pozwala mu na doświadczenie ekstazy. Wizja człowieka w koncepcji duende to wizja jednostki zmiennej, niepewnej, pełnej paradoksów i przeciwieństw, która w godności doświadcza radości i cierpienia. Kreacja jest więc procesem ascezy i wywłaszczania, stanem rozdarcia

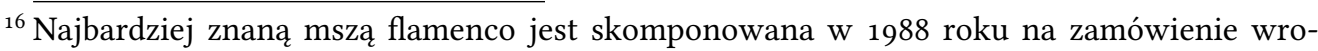
cławskiego festiwalu Vratislavia Cantans Misa flamenca gitarzysty Paco Peña, wystawiona w Wrocławiu w 1991 roku. Z 1991 roku pochodzi też Misa flamenca Enrique Morente. Paco Peña. Misa Flamenca; Misa flamenca, „Pismo folkowe”.

17 „Todas las artes, y aun los países, tienen capacidad de duende, de ángel y de musa; y así como Alemania tiene, con excepciones, musa, y la Italia tiene permanentemente ángel, España está en todos tiempos movida por el duende” (tłum. K. Hliniak), (García Lorca 1993, 5, tłum. K. Hliniak; Diez de Prado 2009 25-26). 
i bezradności, pozbywaniem się a nie korzystaniem z posiadanych talentów (Martínez Hernández 2011, 93-94).

Dynamiczny i kreacyjny potencjał duende podkreśla Lorca w ostatniej części swojego traktatu pytając:

Gdzie znajduje się duende? Przez pusty łuk wchodzi wiatr idei, który uporczywie wieje nad głowami umarłych, w poszukiwaniu nowych krajobrazów i pomijanych rzeczy ważnych: powietrza o zapachu śliny dziecka, zmiażdżonej trawy i welonu meduzy, który zapowiada ciągły chrzest rzeczy nowo utworzonych. ${ }^{18}$

Cytowana przez Roderyka Langego Maria Sobolewska-Drabecka pisząc o magicznej roli tańca charakteryzuje połączenie w nim tego, co zewnętrzne i wewnętrzne, także widząc w tym kreację nowego stanu, odmiennego od jego części składowych:

Forma i jej treść łączą się i wspólnie unoszą umysł ponad obojętny stan emocjonalny typowy dla życia codziennego (Lange 2009, 91).

Wprowadzanie człowieka w nowy, inny od typowego stan, charakteryzuje kultury prymarne, w których taniec odgrywał funkcję magiczną i obrzędową (Lange 2009, 123). Bliskie byłoby również mistycznej roli, jaką poezji przypisywał Platon (Tatarkiewicz 2011, 112) a także zbliżone jest do działania duende. W ten sposób sztuka flamenco nie byłaby grecką techne - umiejętnością, ale stawałaby się poiesis - obrzędem, działaniem pozwalającym na łączność ze światem idealnym, współuczestniczeniem w kreacji, stawaniem się a nie tylko naśladowaniem. Jeszcze bardziej związki koncepcji duende i poiesis Platona widać, kiedy Lorca pisze:

Wszystkie sztuki mają potencjał duende, jednak najwięcej miejsca dla niego znajduje się, co naturalne, w muzyce, tańcu i mówionej poezji, które wymagają żywego ciała, aby je zinterpretować, ponieważ są formami, które

18 „¿Dónde está el duende? Por el arco vacío entra un aire mental que sopla con insistencia sobre las cabezas de los muertos, en busca de nuevos paisajes y acentos ignorados: un aire con olor de saliva de niño, de hierba machacada y velo de medusa que anuncia el constante bautizo de las cosas recién creadas" (tłum. K. Hliniak).

Hiszpański zwrot aire mental - dosłownie: powietrze umystu rozumiany literalnie jako synonimiczne z viento de la razón - wiatr rozumu, przetłumaczone zostało tutaj bardziej ogólnym zwrotem wiatr idei. Duende, jak pisze o nim Lorca, jest pojęciem wieloznacznym, jest walka a nie myśleniem, moca a nie dzietem, aktem tworzenia, które wypływa z wnętrza człowieka i nie jest związane z racjonalnym działaniem (García Lorca 1933, 2, 11). 
stale rodzą się i umierają, i otwierają swoje kontury wyłącznie w chwili obecnej. ${ }^{19}$

W fantazmacie na temat duende warte zauważenia jest więc spójne i zależne od siebie istnienie we flamenco tych samych działań, które charakteryzowały czynności greckiego kapłana lub poety: muzyki, śpiewu i tańca. Osoby, która wchodzi w kontakt ze światem nadprzyrodzonym i dotyka sytuacji granicznych (Tatarkiewicz 2006, 294-295). W myśleniu o flamenco to dopiero wspólne występowanie tych trzech dziedzin sztuki oraz działanie duende może stworzyć występ doskonały, uważany za najbliższy ideałowi. Artysta, a raczej artyści, jako cuadro flamenco stawaliby się poniekąd kapłanami tej sztuki, którzy tylko wyrażają wewnętrzną rzeczywistość ogarniającego ich demona. Gdy nad artystami władzy nie przejmuje duende, nawet gdy tańczą, śpiewają i grają, są oszustami, a to co ukazują pozbawione jest prawdziwych uczuć (García Lorca 1933, 3). Przez teorię duende Lorca pokazuje więc nowy związek między sztuką a prawdą, między etyką a estetyką. W ten sposób poeta daje odpowiedź, która $z$ form kreacji flamenco jest autentyczna i najbliższa ideałowi i jakimi kryteriami powinni się kierować jego twórcy.

Sztuka stawiana jest przez poetę na równi z religią i filozofią, jako dziedzina która pomaga człowiekowi odpowiedzieć na najważniejsze pytania: o śmierć i prawdę o sobie samym i nie jest to odpowiedź pesymistyczna (Martínez Hernández 2011, 93-94, 97-98). Tak o teorii Lorki pisze José Martínez Hernández:

Sztuka jest w niej rozumiana jako cudowna mieszanka jasności, odwagi, pobożności i niewinności, jako spojrzenie, które każdego dnia kontempluje ze zdumieniem i entuzjazmem świt świata. ${ }^{20}$

Podobnie też jak czynności kapłana w starożytnej Grecji i w kulturach prymarnych, twórczość artysty nie byłaby tylko działaniem dla egoistycznego dobra jednostki ją tworzącej. To aktywność, której celem jest tworzenie wspólnoty. Na takich założeniach oparte są również zasady obowiązujące w trakcie spotkania lub spektaklu flamenco, który ma łączyć wykonawców na scenie i artystów z publicznością (Martínez Hernández 2011,94).

Opisana, a właściwie wykreowana przez Lorkę w jego wierszach, poematach i pracach, wizja duende jest obecna w kulturze do dzisiaj. Okazała się

20 „En ella el arte es entendido como una prodigiosa mezcla de lucidez, coraje, piedad e inocencia, como una mirada que contempla cada día con asombro y entusiasmo el amanecer del mundo” (Martínez Hernández 2011, 98, tłum. K. Hliniak). 
bardzo pociągająca, zarówno dla twórców, jak i widowni flamenco. Zaowocowała wieloma interpretacjami artystycznymi, które tak jak Yerma Cristiny Hoyos i Mariana Pineda Sary Baras albo wprost odwołują się do twórczości Lorki i są jej adaptacjami, albo nawiązują do samej idei duende.

Wśród innych niż sceniczne nawiązań do mitów na temat duende, losu Gitanos i ze względu na kreowany wizerunek flamenco trzeba wymienić filmy Carlosa Saury: Bodas de sangre (Krwawe gody, 1981), Carmen (1983), El amor brujo (Miłość czarnoksiężnikiem, 1986), Sevillanas (1993), Flamenco (1995), Iberia (2005), Flamenco, flamenco (2010). W podobny sposób Gitanos scharakteryzował Tony Gatlif w Gadjo Dilo (1997), Vengo (2000) i Exils (2004), jak też Dominique Abel w półdokumentalnym filmie Poligono Sur z 2003 roku. Gitanos poświęcono serię dokumentalną pod symbolicznym tytułem $E l$ Ángel. Musical Flamenco i książkę Jasona Webstera Duende. W poszukiwaniu flamenco.

Razem ze wspomnianymi spektaklami tanecznymi powyższe dzieła ugruntowały wizję flamenco jako zdarzenia poddanego działaniu duende, nad którym wykonawcy nie mają pełnej kontroli. Jednocześnie rozwijają one i przybliżają odbiorcy mit Andaluzji, Hiszpanii i cygańskości, który w ten sposób stał się stałym toposem kultury globalnej ${ }^{21}$.

Przedstawiona wyżej wizja flamenco, szczególnie w odniesieniu do kreacji choreografii czy występu tanecznego, choć bardzo pociągająca, jest oczywiście niepełna i ostatecznie nieprawdziwa. Należy - podobnie jak część opowieści o historii tej sztuki - do fantazmatów na jej temat. Warto więc na koniec przyjrzeć się tym czynnościom artysty flamenco, które kreują pokaz i mają pozwalać osiągnąć stan określany mianem duende.

\section{Fantazmat duende a świadoma kreacja artystyczna}

Studiowanie flamenco to zapoznawanie się z zasadami tworzącymi ten gatunek, co pozornie przypomina (i bywa tak przedstawiane) kolejne etapy wtajemniczenia. To początkowo bardziej greckie episteme - zdobywanie wiedzy,

${ }^{21}$ Carlos Saura; Tony Gatlif; Poligono Sur, Internet Movie Database (IMDb). Seria telewizyjnych filmów dokumentalnych El Ángel. Musical Flamenco w reżyserii Ricardo Pachóna nagrana została w 1984 roku, składa się z 6 odcinków dostępnych na płytach DVD. Opis odcinków w języku hiszpańskim dostępny jest online: El Ángel. Musical Flamenco, http://jondoweb.com. 
niż techne - nabywanie umiejętności praktycznych. To, co ukazywane jest na scenie i postrzegane jako działanie quasi magiczne, oprócz biegłości technicznej, jest bowiem wynikiem poznania określonych struktur poszczególnych stylów flamenco. To również efekt precyzyjnie zdefiniowanych i ustalonych relacji śpiewu, tańca i muzyki względem siebie, które występują w cuadro flamenco (Hliniak 2017, 106-107).

Nauka flamenco zaczyna się od poznania compás - podstawowej struktury rytmicznej tego gatunku i zaznajomienia się z reloj flamenco - zegarem rytmów flamenco (Zgraja 1995, 23, Leblon 1995, 151-153). Charakteryzujący część stylów rytm 12/4 i sposób rozłożenia akcentów w takich palos jak bulerías, soleáres czy alegrías może w odbiorze widza tworzyć klimat swoistego transu ${ }^{22}$. Elementem nieodłącznie związanym z rytmem jest palmas klaskanie. Palmas łączy wykonawców, pomaga gitarzyście, tańczącym i śpiewakowi w utrzymaniu rytmu i tempa utworu, a na widzach zawsze wywiera szczególne wrażenie (Zgraja 1995, 17).

Charakterystyczny, ekspresyjny układ i praca dłoni mogą również być elementem tworzącym magię występu flamenco. Dynamiczne gesty, floreo kręcenie dłońmi kółek i ósemek oraz charakterystyczne porte de bras, czyli braceo flamenco mogą z daleka kojarzyć się nieświadomemu widzowi z magicznymi działaniami wiedźmy lub kapłana, czy kapłanki tajemniczej religii. Postać wiedźmy - bruja - jest motywem wykorzystywanym w spektaklach flamenco. Jedna z najwybitniejszych tancerek flamenco, Cristina Hoyos, w realizowanym w 2003 roku na podstawie dramatu Lorki spektaklu Yerma odgrywała właśnie rolę Vieja Pagana, czyli wiedźmy. Tancerka ta wypracowała własną stylistykę ruchu rąk i dłoni, którą charakteryzuje wyjątkowa ekspresja ${ }^{23}$. Rozpoznawalna pośród innych technik tanecznych praca dłoni i rąk we flamenco jest prawdopodobnie dalekim echem indyjskich mudr gestów stosowanych w klasycznym tańcu indyjskim lub też wpływów związanych z kontaktami mieszkańców Indii i przodków Gitanos z dziedzictwem kulturowym ludów Środkowego Wschodu (Ficowski 2000, 8).

Na publiczności wrażenie wywiera również zapateado - rytmiczna praca nóg, która jest nieco podobna do stepu w tańcu jazzowym lub irlandzkim.

${ }^{22}$ Akcentowane wartości w rytmie $12 / 4$ to: 3, 6, 8, 10 i 12 . W bulerías stosowana jest też odmiana akcentowania rytmu zwana soniquete, w której akcenty padają na wartości 3, 7, 8, 10 i 12 compás. Rozłożenie akcentów rzadsze na 3 i 6, a potem ich zagęszczenie w dalszej części compás tworzy pulsację, która wciąga wykonawców i widzów.

${ }^{23}$ Museo del baile flamenco. Cristina Hoyos; Cristina Hoyos - "Yerma" - Jardines del Generalife - Granada. 
W strukturach poszczególnych palos ujęte są części, które służą popisowi tancerza i ukazaniu jego mistrzostwa $\mathrm{w}$ tym zakresie ${ }^{24}$. Zapateado wygląda na skomplikowane, ale składa się z kilku prostych elementów. Maestria polega na ich odpowiednim połączeniu, szybkości wykonania i utrzymywaniu się tańczącego w strukturach rytmicznych charakteryzujących dane palo (Hliniak 2017, 99-100, Żebrowska-Kacprzak 2011, 42-43).

Tajemnicza i często niezrozumiała dla widzów jest struktura utworu flamenco. Tak był postrzegany taniec cygański przez dziewiętnastowiecznych obserwatorów, takim był świadomie kreowany przez lata i dzisiaj takie ujęcie tej sztuki prezentują często sami wykonawcy. W potocznych opiniach na jego temat, szczególnie poza Hiszpanią, dominuje przekonanie, że flamenco jest spontaniczne i improwizowane, a artysta przez nie wyraża własną ekspresję. Tancerz ma być niesiony duende, walczyć z nim i jemu się poddawać. Nagłe zerwania w muzyce, zatrzymania w ruchu, eskalujące do niemożliwości tempo i narastająca dynamika miałyby być efektem działania demona. Ta porywająca wizja, wraz z odwoływaniem się do mitu cygańskości jest też elementem marketingu szkół flamenco. Palos mają jednak swoje struktury i analizując je możemy wyznaczyć podstawowe elementy kompozycji typowe dla większości stylów flamenco, a śledząc utwór określić i nazwać części, z których jest zbudowany. Nie oznacza to, że nie zdarzają się odstępstwa od przyjętych regul, ich zmiana czy negacja, ale są to zazwyczaj świadome zabiegi (Linares 1996, 188-215, Sánches González 2011, 26).

Na koniec, wśród środków, które budują szczególną atmosferę występu flamenco należy wymienić towarzyszące przedstawieniom i częściowo wspominane już wcześniej akcesoria, takie jak: mantón - chusta, abanico wachlarz, flores - kwiaty, pendientes - kolczyki, peineta - ozdobny grzebień, bata de cola - tren i szeroka spódnica z falbanami (Hliniak 2017, 108).

Kontynuując analogię między działaniami greckiego kapłana i osoby kierowanej przez duende można powiedzieć, że tak jak do rytuału religijnego potrzebny jest nie tylko ktoś sprawujący obrzędy, ale też określone przepisy i zestaw przedmiotów, których używa, tak do występu flamenco potrzebne jest episteme - wiedza na temat stylów, struktur i zasad, techne - praktyczna biegłość w tej dziedzinie, jak też odpowiednie miejsce i akcesoria

${ }^{24}$ Potocznie zamiennie używa się określeń zapateado i stepowanie flamenco. Jest też styl tańca zapateado para bailar polegający na popisie w zakresie umiejętności stepowania do akompaniamentu gitarzysty, które cechuje rytmiczne naśladownictwo fraz gitarowych przez tancerza. 
wykorzystywane przez wykonawców. Dopiero połączenie tych cech może sprawić, by pokaz flamenco, dzięki działaniu duende, zbliżał się do poiesis.

\section{Zakończenie}

Na relację twórczości i odtwórczości we flamenco można patrzeć z bardzo różnych perspektyw. $Z$ punktu widzenia mitu jest to działanie duende, które jako takie pozostaje poza wpływem wykonawcy. Jest to też przedstawienie fantazmatów na temat tego jak kształtowała się ta sztuka i ukazywanie wyobrażeń na temat jej historii.

Przyglądając się występom z perspektywy historyka tańca widoczne będą w tej stylistyce: dzieje hiszpańskiej muzyki, śpiewu i tańca, lokalny, narodowy i ogólnoeuropejski kontekst kulturowy, w którym żyli przedstawiciele tamtejszego społeczeństwa, sytuacja andaluzyjskiej bohemy i miejskiego plebsu oraz los tamtejszych Gitanos.

Z punktu widzenia publiczności będzie to dziedzina sztuki, która dostarcza wzruszeń i emocji, a jej - jak też artystom - pozwala przeżywać duchowe katharsis.

Z perspektywy twórcy i badacza flamenco to stylistyka łącząca muzykę, taniec i śpiew, na którą składają się określone struktury rytmiczne i melodyczne, wzorce ruchowe i ustalone zasady, którymi kierują się wykonawcy na scenie. W zależności od podzielanego przez artystę wzorca flamenco, będzie to stylistyka, której zadaniem jest realizowanie ideału flamenco puro, albo przestrzeń do wyrażania własnej wolności twórczej lub podejmowania fuzji artystycznych łączących flamenco z innymi dziedzinami sztuki czy tradycjami kulturowymi.

Możliwe zresztą, że sprzeczność między tymi postawami jest pozorna. Wizja duende, który ogarniając twórcę pozwala mu na uczestniczenie $\mathrm{w}$ akcie tworzenia, jest bowiem wizją dynamiczną i przekraczającą sztywne reguły, bo jak pisze Lorca „Pojawienie się duende zawsze oznacza radykalną przemianę wszystkich form" 25 .

Tak zreinterpretowany ideał duende mógłby więc dać przestrzeń twórczej kreacji a tym samym pole do fuzji z innymi tradycjami muzycznymi czy tanecznymi. Ta wizja byłaby bliska koncepcji kreacji flamenco przedstawianej przez Steingressa.

25 „La llegada del duende presuponesiempre un cambio radical entodaslasformas” (García Lorca 1933,4$)$. 
Pytania o wzajemne zależności i miejsce mimesis i duende $\mathrm{w}$ sztuce flamenco zapewne zawsze będą otwarte. Odpowiedź na nie zależy bowiem zarówno od intencji przyjętych przez wykonawców, jak i tego, którą z przedstawionych wizji tworzenia dzieła flamenco wybrał artysta. Każdy z nich może mieć bowiem własne wyobrażenie wzorca flamenco i stanu, który utożsamia z działaniem duende. Odpowiedź na to zagadnienie leży być może także po stronie odbiorców tej sztuki, którzy zgodnie ze współczesnym pojmowaniem ich roli, sami także stają się twórcami, a odbieranemu przez nich dziełu nadają nowe znaczenia.

\section{Bibliografia}

Acerca del enorme racismo de la cantante Rosalía hacia el pueblo romaní. Dostęp: 03.06.2020.

Acusan a Rosalía de «desgitanizar» la canción de los Chunguitos que cantóen los Goya. Dostęp: 25.09.2019.

Adamczyk, Anita. 2011. „Romni wśród Romów. Kobieta w kulturze romskiej”. Przeglad politologiczny Nr 2 (2011). Poznań: Wydawnictwo Naukowe UAM.

Aszyk, Urszula. 1997. Federico García Lorca w teatrze swoich czasów. Warszawa: Energeia.

Ballet Flamenco de Andalucía. Dostęp: 20.09.2019.

Ballet Nacional de España. Dostęp: 20.09.2019.

Bartosz, Adam. 2003. Tabor Pamięci Romów. Roma caravan memorial. Tarnów: Gmina Miasta Tarnowa. Muzeum Okręgowe w Tarnowie.

Burszta, Józef. 1985. Chtopskie źródta kultury. Warszawa: Ludowa Spółdzielnia Wydawnicza.

Carlos Saura. Internet Movie Database (IMDb). Dostęp: 25.07.2019.

Copla. W Diccionario de la lengua española, Real Academia Española. Dostęp: 25.07.2019.

Cristina Hoyos - 'Yerma' - Jardines del Generalife - Granada. Dostęp: 13.05.2020.

De Prado Diez, Diego. 2009. „Teoría y juego del duende de García Lorca: Una visión profunda de la creatividad”. Creatividad y Sociedad nr 14. Asociación para la Creatividad. Dostęp: 25.07.2019.

Dowgiało, Emilia. 2018. O flamenco polskim piórem... Kulturowe realia $i$ stowne bariery. Wrocław: Wydawnictwo Wyższej Szkoły Filologicznej. Dostęp: 28.04.2020. 
El Ángel. Musical Flamenco. Dostęp: 25.07.2019.

Ficowski, Jerzy. 2000. Cyganie w Polsce - dzieje i obyczaje. Gdańsk: Tower Press.

Fiesta. W Diccionario de la lengua española, Real Academia Española. Dostęp: 24.07.2019.

Fraser, Angus. 2001. Dzieje Cyganów. Warszawa: Państwowy Instytut Wydawniczy.

Gagat. Dostęp: 24.07.2019.

Goldbach, Theresa. 2014. Fascism, flamenco, and ballet español. Nacional flamenquismo. Albuquerque: The University of New Mexico. Dostęp: 1.06.2018.

Grzybowski, Juliusz. 2006. „Próba ugruntowania pojęcia tańca w świetle filozofii Arystotelesa ze Stagiry”. Praca doktorska wykorzystana za zgodą autora. Uniwersytet Wrocławski. Wrocław.

Hliniak, Krzysztof. 2017. „Flamenco - zdarzenie magiczne, czy wiedza? Fantazmaty o nauczaniu i kreacji tańca”. Studia Choreologica, Vol. XVIII. Polskie Forum Choreologiczne. Poznań.

. 2018. „Flamenco zdarzenie magiczne, czy wiedza? Fantazmaty na temat pochodzenia Gitanos, nazwy ich sztuki i jej twórcach”. Studia Choreologica, Vol. XIX. Polskie Forum Choreologiczne. Poznań.

- 2019. „Flamenco zdarzenie magiczne, czy wiedza? Fantazmaty na temat tańca tradycyjnego". Studia Choreologica, Vol XX. Polskie Forum Choreologiczne. Poznań.

Lange, Roderyk. 2009. O istocie tańca i jego przejawach w kulturze. Poznań: Rhytmos.

Leblon, Bernard. 1995. Los Gitanos, Historia del Flamenco. (ed.) J. L. Navarro Garcia, M. Ropero Nuñez. Sevilla: Ediciones Tartessos.

Linares, Patricia. 1996. Introducción al studio profesional del baile flamenco. Mexico: JGH Editores.

Malska, Magdalena. 1998. Filozofia baletu. Kraków: Fall.

Manuel Liñán. Dostęp: 1.06.2020.

Mariana Pineda. Dostęp: 21.05.2020.

Martínez Hernández, José. 2011 . „La teoría estética de Federico García Lorca”. W Art, Emotion and Value. 5th Mediterranean Congress of Aesthetics, $M^{a}$ José Alcaraz, Matilde Carrasco y Salvador Rubio (eds.). Dostęp: 15.05.2020.

„Misa flamenca”. Pismo folkowe. Dostęp: 17.05.2020. 
Molina, Ricardo. 1996. „La partipación del elemento gitano en la creación y mantenimiento del cante flamenco". Revista de Flamencología, Año II, Núm. $3-1^{\circ}$. Semestre 1996. Cádiz: Cátedra de Flamencología de la Universidad de Cádiz.

Museo del baile flamenco. Cristina Hoyos. Dostęp: 2.06.2020.

Oxford - Wielka Historia Świata. T. 17. Średniowiecze. Cesarstwo Niemieckie Arabowie na pótwyspie pirenejskim. 2006. Poznań: OXFORD Educational Sp. z o. o.

Paco Peña. Misa Flamenca. Dostęp: 17.05.2020.

Poligono Sur. Internet Movie Database. Dostęp: 25.07.2019.

Representative List of the Intangible Cultural Heritage of Humanity. Dostęp: 24.07.2019.

Ríos Ruiz, Manuel. 1997. Ayer y hoy del cante flamenco. Madrid: Ediciones Istmo.

Roldán Cruces, Cristina. 2012. „El flamenco”. Expresiones culturales andaluzas. Aconcagua Libros: Sevilla. Dostęp: 29.04.2020.

Romanipen. Dostęp: 01.06.2020.

Romano Atmo. Dwumiesięcznik, nr 5/2011 (11). Dostęp: 1.06.2020.

Sánches González, Mónica. 2011. „Estructura básica del baile flamenco”. Revista del Centro de Investigación Flamenco Telethusa nr 4, vol. 4. Dostęp: 25.07.2019.

Steingress, Gerhard. 2005. „La hibridación transcultural como clave de la formación del nuevo flamenco". Musica oral del Sur, Revista Internacional, nr 6. Granada. Dostęp: 28.04.2020.

Tablao. W Diccionario de la lengua española. Real Academia Española. Dostęp: 25.07.2019.

Tatarkiewicz, Władysław. 2006. Dzieje sześciu pojęć. Warszawa: PWN.

- 2011. Historia filozofii, t. I, wyd. XXII. Warszawa: PWN.

„Tony Gatlif”. Internet Movie Database. Dostęp: 25.07.2019.

Turska, Irena. 1983. Krótki zarys historii tańca i baletu. Warszawa: Polskie Wydawnictwo Muzyczne.

—. 2014. Przewodnik baletowy, Kraków: Polskie Wydawnictwo Muzyczne.

Wieczorek, Marta. 2018a. Flamenco. Studium $z$ antropologii semiotycznej. Kraków: Wydawnictwo Uniwersytetu Jagiellońskiego.

. 2018b. „Flamenco: Contemporary Research Dilemmas”. Łódzkie Studia Etnograficzne, tom 57, Łódź. Dostęp: 28.04.2020. 
Wysocka, Tacjanna. 1970. Dzieje baletu. Warszawa: Państwowy Instytut Wydawniczy.

Zarzuela. W Diccionario de la lengua española, Real Academia Española. Dostęp: 25.07.2019.

Zgraja, Krzysztof. 1995. Flamenco. Historia, teoria, praktyka. Gdynia: Polskie Stowarzyszenie Jazzowe.

Żebrowska-Kacprzak, Urszula. 2011. Flamenco na polskiej scenie. Kraków: Polskie Wydawnictwo Muzyczne. 


\title{
Abstract, keywords, about the author
}

\begin{abstract}
The paper describes the relationship between imitation and creativity in flamenco style, referring them to the Greek concept of mimesis and comparing it with the duende concept present in this genre. Although both ideas are separated by two thousand years, they transpire to be unexpectedly convergent in their basic premises.

In order to present the phenomenon of duende, the author also attempts a short answer to the question of what the phenomenon of flamenco is, what conditioned its emergence, what its characteristics are, and what forms and styles of flamenco can be currently found. Describing the phantasms about duende and a flamenco show, the author presents the process of creating a flamenco performance and its choreography.

The paper refers to the accomplishments of the acclaimed Polish philosopher Władysław Tatarkiewicz, and is also a tribute to the late professor Jagna Dankowska, a sound director, a Professor of Philosophy, a Professor at the Fryderyk Chopin University of Music in Warsaw, who inspired the author to write this text.
\end{abstract}

Keywords: flamenco, duende, mimesis, Federico García Lorca, imitation

Krzysztof Huiniak, PhD student at the Centre for the Comparative Studies of Civilisations at the Jagiellonian University; a graduate of history and postgraduate studies in cultural management at this university, postgraduate studies in dance theory at the Fryderyk Chopin University of Music and the Instructor Qualification Course in Contemporary Dance at the Ministry of Culture and National Heritage; teacher; since 2018/2019 academic year he has been leading research on the history of dance in Krakow and the region, as part of grants from the program Biate plamy - muzyka i taniec of the Institute of Music and Dance in Warsaw; he has published in the Studia Choreologica magazine, the Taniec quarterly and on the website taniepolska.pl; member of the Polish Forum of Choreology Association and the Dance Art Community Forum Association. His interests include anthropology of dance and the issue of dance heritage.

E-MAIL: krzysztofhliniak@gmail.com 